
Research Divisior which may be borrowed for two weeks.

Submitted to the Journal of catax yoss

EFFECTS OF METAL-SUPPORT INTERACTIONS ON THE SYNTHESIS OF METHANOL OVER PALLADIUM

Yu. A. Ryndin, R.F. Hicks, A. T. Bel1, and

Yu. I. Yermakov

Apri1 1980

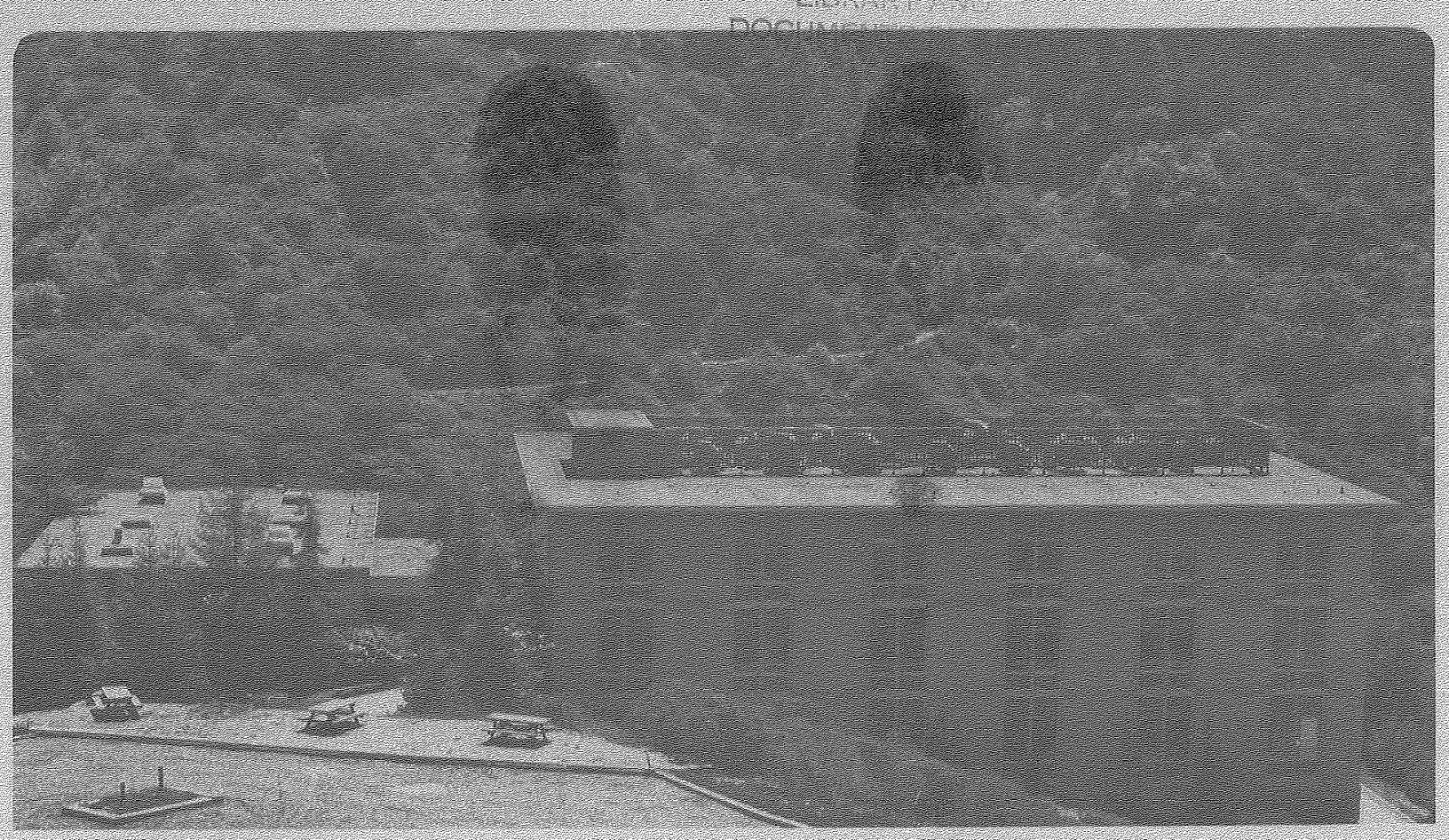

Prepared for the U.S. Department of Energy under Contract W-7405-ENG-48 


\section{DISCLAIMER}

This document was prepared as an account of work sponsored by the United States Government. While this document is believed to contain correct information, neither the United States Government nor any agency thereof, nor the Regents of the University of California, nor any of their employees, makes any warranty, express or implied, or assumes any legal responsibility for the accuracy, completeness, or usefulness of any information, apparatus, product, or process disclosed, or represents that its use would not infringe privately owned rights. Reference herein to any specific commercial product, process, or service by its trade name, trademark, manufacturer, or otherwise, does not necessarily constitute or imply its endorsement, recommendation, or favoring by the United States Government or any agency thereof, or the Regents of the University of California. The views and opinions of authors expressed herein do not necessarily state or reflect those of the United States Government or any agency thereof or the Regents of the University of California. 


\title{
Effects of Metal-Support Interactions on the Synthesis of Methanol over Palladium
}

\section{by}

\author{
Yu. A. Ryndin $\$$, R. F. Hicks, and A.T.Bell \\ Materials and Molecular Research Division \\ Lawrence Berkeley Laboratory
}

and

Department of Chemical Engineering

University of California, Berkeley, California 94720

and

Yu. I. Yermakov

Institute of Catalysis

Novosibirsk 630090, U.S.S.R.

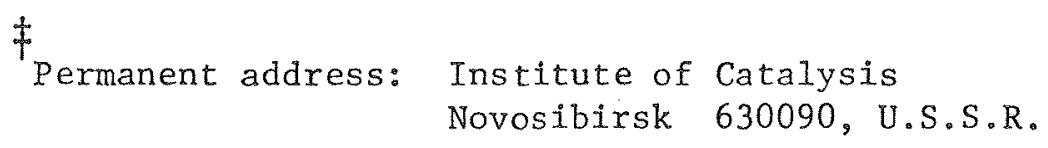

$\ddagger$

Permanent address: Institute of Catalysis

Novosibirsk 630090, U.S.S.R. 
ABSTRACT

The synthesis of methanol and other products from $\mathrm{CO}$ and $\mathrm{H}_{2}$ was studied over $\mathrm{Pd}$ catalysts prepared by adsorption of $\mathrm{Pd}\left(\pi-\mathrm{C}_{3} \mathrm{H}_{5}\right)_{2}$ on $\mathrm{MgO}$, $\mathrm{ZnO}, \mathrm{La}_{2} \mathrm{O}_{3}, \gamma-\mathrm{Al}_{2} \mathrm{O}_{3}, \mathrm{SiO}_{2}, \mathrm{TiO}_{2}$, and $\mathrm{ZrO}_{2}$ as well as over a $\mathrm{SiO}_{2}$-supported Pd catalyst prepared from $\mathrm{PdCl}_{2}$ and Pd black. Both the activity and selectivity of $\mathrm{Pd}$ were affected strongly by the nature of the support and the composition of the Pd precursor. The specific activity for methanol synthesis decreased in the order $\mathrm{Pd} / \mathrm{La}_{2} \mathrm{O}_{3} \gg \mathrm{Pd} / \mathrm{SiO}_{2}$ [derived from $\left.\mathrm{PdCl}_{2}\right]>\mathrm{Pd} / \mathrm{ZrO}_{2}>\mathrm{Pd} / \mathrm{ZnO} \approx \mathrm{Pd} / \mathrm{MgO}>\mathrm{PdTiO}_{2}>\mathrm{Pd} / \mathrm{Al}_{2} \mathrm{O}_{3} \approx \mathrm{Pd} / \mathrm{SiO}_{2}$ [derived from $\mathrm{Pd}\left(\pi-\mathrm{C}_{3} \mathrm{H}_{5}\right)_{2}$ ] $\gg \mathrm{Pd}$ black while the specific activity for hydrocarbon synthesis decreased in the order $\mathrm{Pd} / \mathrm{TiO}{ }_{2}>\mathrm{Pd} / \mathrm{ZrO}_{2}>$ $\mathrm{Pd} / \mathrm{La}_{2} \mathrm{O}_{3}>\mathrm{Pd} / \mathrm{Al}_{2} \mathrm{O}_{3} \approx \mathrm{Pd} / \mathrm{SiO}_{2}$ [derived from $\mathrm{PdCl}_{2}$ ] $>\mathrm{Pd} / \mathrm{SiO}_{2}$ [derived from $\left.\mathrm{Pd}\left(\pi-\mathrm{C}_{3} \mathrm{H}_{5}\right)_{2}\right] \approx \mathrm{Pd} \mathrm{black} \gg \mathrm{Pd} / \mathrm{MgO} \sim \mathrm{Pd} / \mathrm{ZnO}$. Dimethyl ether production was observed over four of the catalysts and the activity for formation of this product decreased in the order $\mathrm{Pd} / \mathrm{Al}_{2} \mathrm{O}_{3} \gg \mathrm{Pd} / \mathrm{TiO}_{2}>>$ $\mathrm{Pd} / \mathrm{MgO} \approx \mathrm{Pd} / \mathrm{ZrO}_{2}$. The effects of support composition on the catalytic properties of $\mathrm{Pd}$ are discussed in the light of current ideas concerning metal-support interactions and the acid-base properties of the support. 


\section{INTRODUCTION}

The selective synthesis of methanol from $\mathrm{CO}$ and $\mathrm{H}_{2}$ over Group VIII metals has been reported in several recent studies (1-5). Poutsma et al. (1) have demonstrated that both silica- and alumina-supported Pd catalyzed the hydrogenation of CO to methanol with high selectivity. Methane formation was found to be significant only outside the temperature pressure regine for which methanol formation is thermodynamically favorable. The behavior of $\mathrm{Pt}$ and Ir were similar but these metals were less active than $P d$. The authors suggested that the attainment of high methanol selectivities might be attributed to the inability of all three metals to chemisorb co dissociatively at reaction temperatures, compared to other Group VIII metals. The synthesis of methanol over $\mathrm{Rh}, \mathrm{Pd}$, Ir, and $\mathrm{Pt}$ has also been investigated by Ichikawa $(2-5)$ in a series of studies carried out at atmospheric pressure. This work has shown that catalyst activity and selectivity depend not only on the choice of metal, but also on the composition of the metal precursor and acid/base properties of the metal oxide support. On a given support much higher methanol activities and selectivities were obtained by pyrolysis of transition metal complexes $\left(\mathrm{e}_{.} \mathrm{g} \cdot \mathrm{R}_{4}(\mathrm{CO})_{12}, \mathrm{Rr}_{4}(\mathrm{CO})_{12}\right.$, $\left[\mathrm{Pt}_{15}(\mathrm{CO})_{30}\right]\left[\mathrm{NEt}_{4}\right]_{2}$, etc.) than by reduction of halogen containing compounds $\left(\mathrm{e} . \mathrm{g} \cdot, \mathrm{RhCl}_{3}\right.$ or $\left.\mathrm{H}_{2} \mathrm{PtCl}_{6}\right)$. High methanol activity and selectivity was further favored by the use of moderately basic supports such as $\mathrm{MgO}, \mathrm{La}_{2} \mathrm{O}_{3}, \mathrm{Y}_{2} \mathrm{O}_{3}$ and $\mathrm{Na}_{2} \mathrm{O}_{3}$. Utilization of strongly basic or

acidic supports such as $\mathrm{Li}_{2} \mathrm{O}, \mathrm{SiO}_{2}, \mathrm{TiO}_{2}$, and $\mathrm{WO}_{3}$ greatly suppressed the synthesis of methanol and elevated somewhat the synthesis of methane. 
The objectives of the present research were to explore further the effects of support composition on the specific activity of $P d$ for the synthesis of methanol and other products. These studies were carried out at 10 atm over the temperature range of 323 to $573 \mathrm{~K}$. Supported Pd catalysts were prepared on $\mathrm{SiO}_{2}, \mathrm{Al}_{2} \mathrm{O}_{3}, \mathrm{TiO}_{2}, \mathrm{ZrO}_{2}, \mathrm{ZnO}, \mathrm{MgO}$, and $\mathrm{La}_{2} \mathrm{O}_{3}$ by reacting bis- $\pi-a 11 y 1$ palladium, $\operatorname{Pd}\left(\pi-\mathrm{C}_{3} \mathrm{H}_{5}\right)_{2}$, with the hydroxyl groups present on the support surface. The selection of this preparative procedure was motivated by the desire to achieve intimate contact between the precursor and the support and was suggested by previous studies $(6,7)$ showing that high precursor dispersion could be realized on $\mathrm{SiO}_{2}$ and $\mathrm{Al}_{2} \mathrm{O}_{3}$. In addition, it was anticipated that by avoiding the presence of halogen in the precursor, more active catalysts might be prepared than those derived from $\mathrm{PdCl}_{2}(1,4)$.

\section{EXPERIMENTAL}

Supports

A summary of the supports used in this work, the conditions of their pretreatment, and their source are listed in Table 1. Enhancement of the surface area of $\mathrm{La}_{2} \mathrm{O}_{3}$ was carried out by hydrolysis of non-porous $\mathrm{La}_{2} \mathrm{O}_{3}$ (Ventron Corp., 99.9\% purity) at $353 \mathrm{~K}$ with subsequent filtering and drying in air at $373 \mathrm{k}$, following the method outlined in reference (8). The powdered $\mathrm{La}(\mathrm{OH})_{3}$ was then pressed into a tablet and dehydrated in vacuum at $573 \mathrm{~K}$. The porous $\mathrm{La}_{2} \mathrm{O}_{3}$ thus obtained was rehydrated at $298 \mathrm{~K}$ with water vapor and then again dehydrated at $493 \mathrm{~K}$ in vacuum before impregnation.

Porous $\mathrm{ZrO}_{2}$ was prepared by coagulation of a colloidal suspension of $\mathrm{ZrO}_{2}$ (Nyacol Inc.) and scrupulous washing of the precipitate with large quantities of distilled water. After drying in air at $373 \mathrm{~K}$, the $\mathrm{ZrO}_{2}$ powder was pressed into a tablet and dehydrated in vacuum at $773 \mathrm{~K}$. 
The average size of the zirconia particles in the original suspension was about $500 \AA$, which corresponds to a final surface area of not more than $20 \mathrm{~m}^{2} / \mathrm{gm}$ for the dried material.

Prior to impregnation by the palladium complex all of the supports were dehydrated in vacuum at $10^{-3}$ Torr for 15 hrs at the temperatures indicated in Table 1. Selection of the dehydration temperature was based on infrared studies of the surfaces of the oxides used (8-11) and was chosen to maximize the concentration of isolated surface hydroxyl groups, capable of reacting with $\mathrm{Pd}\left(\pi-\mathrm{C}_{3} \mathrm{H}_{5}\right)_{2}$. Synthesis of bis-T-a11ylpalladium

Bis-T-allylpalladium was obtained by reacting $\left(\mathrm{C}_{3} \mathrm{H}_{5} \mathrm{PdCl}\right)_{2}$ (Strem Chemicals, Inc.) with a solution of $\mathrm{C}_{3} \mathrm{H}_{5} \mathrm{MgCl}$ in diethylether at $298 \mathrm{~K}$ in an inert atmosphere (6). After distillation of the ether the product compound was extracted with pentane and filtered. Further purification of the $\mathrm{Pd}\left(\pi-\mathrm{C}_{3} \mathrm{H}_{5}\right)_{2}$ was achieved by vacuum sublimation. The yield of the final complex was $\sim 85 \%$, based upon the initial quantity of $\left(\mathrm{C}_{3} \mathrm{H}_{5} \mathrm{PdCl}\right)_{2}$ used.

\section{Catalyst Preparation}

The vacuum dehydrated supports were impregnated with a pentane solution of $\mathrm{Pd}\left(\pi-\mathrm{C}_{3} \mathrm{H}_{5}\right) 2^{\circ}$ A rapid irreversible adsorption of the complex was observed during impregnation, which was accompanied by a fading of the initially yellow-green solution of the complex and a coloration of the support. Following impregnation, the remaining pentane solution was decanted, and the catalyst was washed free of unreacted complex using fresh portions of pentane. The catalyst was then dried in vacuum at $298 \mathrm{~K}$ for $3 \mathrm{hrs}$. Finally, the catalyst was reduced in hydrogen at $573 \mathrm{~K}$ for 15 hrs. 
The catalysts derived from $\mathrm{Pd}\left(\pi-\mathrm{C}_{3} \mathrm{H}_{5}\right)_{2}$ were compared with two other catalysts. The first was a $\mathrm{Pd} / \mathrm{SiO}_{2}$ catalyst prepared by incipient wetness impregnation of Davison 57 silica gel with an aqueous solution of $\mathrm{PdCl}_{2}$. This catalyst was obtained from the Union Carbide Corporation and is identical to that described by Poutsma et al. (1). The second catalyst was a palladiun black (Strem Chemicals, Inc.). Catalyst Characterization

The palladium content of each catalyst was determined by $x$-ray fluoresence and was found to be in good agreement with the metal loadings determined from the amount of palladium complex adsorbed by the supports. The palladium content of silica-supported catalyst obtained from Union Carbide was found to be $7.9 \%$ rather than $4.6 \%$, as had been reported by Poutsma et a1. (1).

Palladium dispersions for most of the catalysts were measured by $\mathrm{H}_{2}-\mathrm{O}_{2}$ titration, using the pulsed flow technique (12-14) to avoid problems associated with $\mathrm{H}_{2}$ absorption (15). Evacuated catalyst samples were placed in the adsorption apparatus without prior exposure to air. In the presence of flowing $\mathrm{H}_{2}$, each catalyst sample was heated to $573 \mathrm{~K}$ over a $1 \mathrm{hr}$. period and then maintained at $573 \mathrm{~K}$ for $12 \mathrm{hrs}$. At the end of this period the hydrogen flow was stopped, and the catalyst was exposed to a flow of argon for $1 \mathrm{hr}$. at $573 \mathrm{~K}$. The catalyst was then cooled to room temperature over a $30 \mathrm{~min}$. period.

A different procedure was used to pretreat the palladium black sample. This catalyst was first heated in flowing argon at $373 \mathrm{~K}$ for $1 \mathrm{hr}$ to drive off adsorbed water and then reduced in flowing $\mathrm{H}_{2}$ at $573 \mathrm{~K}$ for $30 \mathrm{~min}$. At the end of this period the sample was again purged in flowing argon for 1 hr.

The reduced catalyst samples were titrated first with oxygen, then with hydrogen, and finally with oxygen a second time, each titration being 
carried out at room temperature. For Pd supported on $\mathrm{SiO}_{2}, \mathrm{Al}_{2} \mathrm{O}_{3}, \mathrm{ZrO}_{2}$, and $\mathrm{MgO}$, the $\mathrm{O}_{2}$ uptake during the first and second oxygen titrations were nearly identical and equal to one half the $\mathrm{H}_{2}$ uptake during the hydrogen titration. This ratio of the $\mathrm{O}_{2}$ and $\mathrm{H}_{2}$ titers is in agreement with that expected from the stoichiometries of reaction 1 and $2(12,13)$.

$$
\begin{aligned}
& \text { 1. } \mathrm{Pd}-\mathrm{H}+3 / 4 \mathrm{O}_{2} \rightarrow \mathrm{Pd}-\mathrm{O}+1 / 2 \mathrm{H}_{2} \mathrm{O} \\
& \text { 2. } \mathrm{Pd}-\mathrm{O}+3 / 2 \mathrm{H}_{2} \rightarrow \mathrm{Pd}-\mathrm{H}+\mathrm{H}_{2} \mathrm{O}
\end{aligned}
$$

The consistency of the two oxygen titers indicates that very little adsorbed $\mathrm{H}_{2}$ is lost during the argon purge following reduction. For Pd supported on $\mathrm{TiO}_{2}, \mathrm{ZnO}$, and $\mathrm{La}_{2} \mathrm{O}_{3}$, the uptake of $\mathrm{O}_{2}$ during the first oxygen titration was greater than the uptake during the second titration by 40,65 , and $70 \%$, respectively, suggesting that a part of the $\mathrm{O}_{2}$ taken up during the first titration is used to replace oxygen lost from the support during reduction. It was observed, though, that the $\mathrm{H}_{2}$ uptake during the hydrogen titration was twice the $\mathrm{O}_{2}$ uptake during the second oxygen titration in agreement with the stoichiometries of reactions 1 and 2. In view of this, the Pd dispersions for all of the catalysts were determined by averaging the results of the hydrogen titration and the second oxygen titration.

Hydrogen-oxygen titration could not be used on the Pd black or $\mathrm{Pd} / \mathrm{SiO}_{2}$ catalyst obtained from Union Carbide because these matierlas exhibited a large weak adsorption of hydrogen well above the stoichiometric amount, possibly due to $\beta$-hydride formation $(14,16)$. For these catalysts dispersion was determined solely by oxygen titration. 
The dispersions of all of the catalysts used in this study are 1isted in Table 1. For the sake of subsequent discussion, the two $\mathrm{SiO}_{2}^{-}$ supported catalysts have been designated as ${\mathrm{Pd} / \mathrm{SiO}_{2}}_{2}$ (I) and $\mathrm{Pd} / \mathrm{SiO}_{2}$ (II), to differentiate between the use of $\mathrm{Pd}\left(\pi-\mathrm{C}_{3} \mathrm{H}_{5}\right)_{2}$ and $\mathrm{PdCl}_{2}$, respectively, as the metal precursor. It is significant to note that the dispersions for those catalysts prepared by adsorption of $\mathrm{Pd}\left(\pi-\mathrm{C}_{3} \mathrm{H}_{5}\right)_{2}$ lie between 0.2 and 0.6 . These results indicate that the atomic dispersion of $\mathrm{Pd}$ which can be achieved when the complex is reduced at room temperature cannot be retained when reduction is carried out at elevated temperatures. This conclusion is in agreement with that reported earlier for $\mathrm{SiO}_{2}$ and $\mathrm{Al}_{2} \mathrm{O}_{3}$ supported $\mathrm{Pd}(6)$ and indicates that the other supports used in this work are no more effective than $\mathrm{SiO}_{2}$ and $\mathrm{Al}_{2} \mathrm{O}_{3}$ for stabilizing the dispersion of $\mathrm{Pd}$.

\section{Catalyst Evaluation}

Catalyst testing was carried out in a tubular micro-reactor made of stainless steel. Between 0.05 and $1.88 \mathrm{~g}$ (see Table I) of reduced catalyst, in the form of a powder with particles of about 0.50 to $0.25 \mathrm{~mm}$ in diameter, was loaded into the reactor. The reactor was then flushed with helium, and the catalyst was reduced in hydrogen at $573 \mathrm{~K}$. The hydrogenation of $\mathrm{CO}$ was conducted at a total pressure of 10 atm using a $3: 1$ mixture of $\mathrm{H}_{2}$ to $\mathrm{CO}$, over the temperature range of 150 to $300^{\circ} \mathrm{C}$. The

gas flow rate was typically $200 \mathrm{STP} \mathrm{cm}^{3} / \mathrm{min}$. Products were analyzed with a Varian 3700 gas chromatograph fitted with a $1 \mathrm{~m}$ by $2 \mathrm{~mm}$ column packed with Chromsorb-106 and a flame ionization detector. The column temperature was raised from 318 to 513 at a rate of $10 \mathrm{~K} / \mathrm{min}$.

An analysis of the reaction products was conducted 10 min following the onset of reaction, after which the catalyst was reduced for 30 min in hydrogen before reintroducing the reaction mixture. If the analyses of 
consecutive runs at a given temperature were not reproduced, runs were continued until a stationary state of the catalyst was attained, at which point the dependence of catalyst activity on temperature was explored. Following this, the catalyst temperature was returned to that used initially and the catalyst activity was compared with the initially measured values.

RESULTS

Methanol and $C_{1}$ through $C_{6}$ hydrocarbons were observed as the primary products for all of the catalysts tested and only occasionally were traces of ethanol detected. For Pd supported on $\mathrm{Al}_{2} \mathrm{O}_{3}, \mathrm{TiO}_{2}, \mathrm{ZrO}_{2}$, and MgO, dimethyl ether was also observed. Carbon monoxide conversions and product distributions determined at $523 \mathrm{~K}$ are given in Table 2 . It is significant to note that the conversions are small in all cases and lie well below the equilibriur conversion of $10 \%$ for the conditions indicated.

During the evaluation of the catalysts, it was observed that activity of some of the catalysts either increased or decreased with repeated use, the nature and extent of these changes depending on the composition of the support. Figure 1 illustrates the manner in which the activities for methanol and total hydrocarbon synthesis change as a function of the number of runs conducted using $\mathrm{SiO}_{2}-$ and Zno-supported catalysts. It is observed that while the methanol activity of the $\mathrm{Pd} / \mathrm{SiO}_{2}$ catalyst is constant the hydrocarbon activity declines to an asymptotic level after ten runs. The Pd/Zno catalyst exhibits the reverse behavior and in this case it is the methanol activity which increases to an asymptotic level. The stability behavior of the remaining catalysts is summarized in Table 3 . With 
the exception of $\mathrm{Pd} / \mathrm{SiO}_{2}(\mathrm{I})$, all of the catalysts exhibit a stable activity for hydrocarbon synthesis. A somewhat different pattern is observed for the synthesis of methanol. In most cases a stable activity it achieved after three or four runs, during. which the activity increases several fold. However, for $\mathrm{Pd} / \mathrm{SiO}_{2}$ (I), $\mathrm{Pd} / \mathrm{SiO}_{2}$ (II), and $\mathrm{Pd} / \mathrm{La}_{2} \mathrm{O}_{3}$, stable activity is reached within the first $10 \mathrm{~min}$ reaction period. For those catalysts which produce dimethyl ether, the activity of ether formation remains constant as the number of runs increases.

Arrhenius plots for the synthesis of methanol, dimethyl ether, and total hydrocarbons are shown in Figs. 2 through 4, and apparent activation energies determined from these plots are given in Table 2 . It is evident that the support composition has a strong influence on the catalyst activity. The specific activity for methanol synthesis decreases in the order $\mathrm{Pd} / \mathrm{La}_{2} \mathrm{O}_{3} \gg \mathrm{Pd} / \mathrm{SiO}_{2}$ (II) $>\mathrm{Pd} / \mathrm{ZrO}_{2}>\mathrm{Pd} / \mathrm{ZnO} \approx$ $\mathrm{Pd} / \mathrm{MgO}>\mathrm{Pd} / \mathrm{TiO}_{2}>\mathrm{Pd} / \mathrm{Al}_{2} \mathrm{O}_{3} \approx \mathrm{Pd} / \mathrm{SiO}_{2}(\mathrm{I})>\mathrm{Pd} \mathrm{black}$. The apparent activation energy for this process is $15.8 \pm 1.8 \mathrm{kcal} / \mathrm{mole}$ for the supported catalysts, but is $10.2 \mathrm{kcal} / \mathrm{mole}$ for Pd black. However, there is no clear-cut correlation between specific activity and activation energy. Dimethyl ether formation is observed over only four of the catalysts examined, and the specific activity for the formation of this product is observed to decrease in the order $\mathrm{Pd} / \mathrm{Al}_{2} \mathrm{O}_{3} \gg \mathrm{Pd} / \mathrm{TiO}_{2} \gg \mathrm{Pd} / \mathrm{MgO} \approx \mathrm{Pd} / \mathrm{ZrO}_{2}$. The apparent activation energy for dimethyl ether formation is $24.0 \pm 0.5 \mathrm{kcal} / \mathrm{mole}$ and does not appear to depend very strongly on the nature of the support. The support composition is also seen to affect the specific activity of $\mathrm{Pd}$ for the formation of hydrocarbons but in a manner different from that in which it affects the methanol synthesis activity. As seen in 
Fig. 4, the specific activity for total hydrocarbon formation decreases in the order $\mathrm{Pd} / \mathrm{TiO}_{2} \sim \mathrm{Pd} / \mathrm{ZrO}_{2}>\mathrm{Pd} / \mathrm{La}_{2} \mathrm{O}_{3}>\mathrm{Pd} / \mathrm{Al}_{2} \mathrm{O}_{3} \approx$

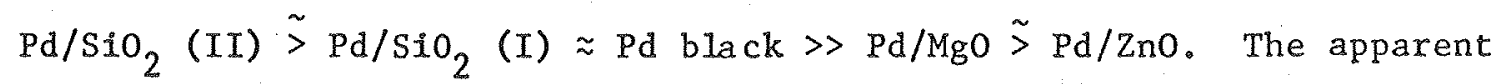
activation for hydrocarbon formation is $24.0 \pm 1.5 \mathrm{kcal} / \mathrm{mole}$ and is approximately the same for supported and unsupported Pd.

The composition of the support also affects the product distribution. As may be seen in Table 2, methanol selectivities of 92 to $100 \%$ are obtained when $\mathrm{Pd}$ is supported on $\mathrm{SiO}_{2}, \mathrm{MgO}, \mathrm{La}_{2} \mathrm{O}_{3}$, and Zno. Very little, if any, dimethyl ether is formed over these catalysts. A high selectivity to oxygenated products, $95.9 \%$, is also observed for the $\mathrm{Al}_{2} \mathrm{O}_{3}$-supported catalyst, but in this instance the methanol selectivity is only $32.5 \%$, the balance of oxygenated products being dimethyl ether. The $\mathrm{TiO}_{2}$ and $\mathrm{ZrO}_{2}$-supported catalysts stand out from all the others because of their low selectivities for the formation of oxygenated products and theix correspondingly high selectivities for hydrocarbon formation. Palladium black exhibits a similar behavior to these latter two catalysts.

Figure 5 and Table 2 show that the support composition has a strong influence on the distribution of hydrocarbons formed. As may be seen in Fig. 5 in most instances the percentage of $\mathrm{CO}$ converted to a hydrocarbon containing $\mathrm{n}$ carbon atoms decreases monotonically as $\mathrm{n}$ increases. Exceptions to this pattern are found for the $\mathrm{MgO} \mathrm{Al}_{2} \mathrm{O}_{3}$, and $\mathrm{La}_{2} \mathrm{O}_{3}-$ supported catalysts, which produce higher yields of $\mathrm{C}_{6}$ hydrocarbons than anticipated. Attention is also drawn to the $\mathrm{TiO}_{2}$ and $\mathrm{ZrO}_{2}$-supported catalysts since the methane selectivity is particularly high for these catalysts. Table 2 shows that the specific activity for methane synthesis over these catalysts is much greater than that observed for any of the remaining catalysts. 


\section{DISCUSSION}

The observed increase in the activity of $\mathrm{Pd}$ when it is supported on metal oxides parallels in some respects the observations reported by Vannice (17). In studies conducted at atmospheric pressure he noted that the methanation activity of $\mathrm{Pd}$ supported on $\mathrm{SiO}_{2}$ and $\mathrm{n}-\mathrm{Al}_{2} \mathrm{O}_{3}$ was higher than that of Pd black and that the activity increased in the order $\mathrm{Pd} / \mathrm{n}^{\mathrm{Al}} \mathrm{Al}_{2} \mathrm{O}_{3} \gg \mathrm{Pd} / \mathrm{SiO}_{2}>\mathrm{Pd}$ black. The results presented in Table 2 show that the hydrocarbon synthesis activity does increase somewhat when $\mathrm{Pd}$ is supported on $\mathrm{SiO}_{2}$ and $\mathrm{\gamma}-\mathrm{Al}_{2} \mathrm{O}_{3}$ but that a much more dramatic increase is observed in activity for the synthesis of oxygenated products. The fallure of Vannice (17) to observe methanol formation is not surprising since his studies were conducted at temperatures of $548 \mathrm{~K}$ and above. Equilibrium calculations show that at one atmosphere and such high temperatures the formation of methane will be favored strongly over the formation of methanol (1).

The exceptionally high methanol synthesis activity of $\mathrm{Pd} / \mathrm{La}_{2} \mathrm{O}_{3}$ relative to the other catalysts tested confirms the results obtained by Ichikawa (4) in studies conducted at atmospheric pressure. The activation energies for methanol formation are also in good agreement-a value of $13.0 \mathrm{kcal} / \mathrm{mole}$ being reported by Ichikawa and a value of $14.0 \mathrm{kcal} / \mathrm{mole}$ being found in the present work. However, it is significant to note that the activity of the $\mathrm{Pd} / \mathrm{La}_{2} \mathrm{O}_{3}$ catalyst used in the present studies appears to be considerably higher than that prepared by Ichikawa starting from $\mathrm{PdCl}_{2}$. Examination of Table 4 shows that if Ichikawa's results are extrapolated to the conditions of the present studies, it is concluded that the catalyst used in the present work is twenty fold more active for methanol synthesis and about two fold more active for methane synthesis. A part of this difference may be ascribed to the differences in $\mathrm{Pd}$ 
loading. Ichikawa obseryed that with increasing Pd content the methanol activity reached a maximum value at about $0.5 \%$ and then decreased to an asymptotic level for loadings between 1 and $5 \%$, the ratio of the maximum activity to that observed at loadings of a few percent being about three. The remaining portion of the difference between Ichikawa's catalyst and that described here is very likely associated with differences in the nature of the palladium precursor and the origin and pretreatment of the support. Thus, Ichikawa observed (4) that the methanol synthesis activity of supported Pt catalysts was five to ten times lower when $\mathrm{H}_{2} \mathrm{PtCl}_{6}$ was used as the source of $\mathrm{Pt}$ than when $\left[\mathrm{Pt}_{3}(\mathrm{CO})_{6}\right]_{3-5} \cdot\left[\mathrm{NEt}_{4}\right]_{2}$ was used as the precursor. The differences between the two $\mathrm{Pd} / \mathrm{SiO}_{2}$ catalysts examined in this work might also be ascribed to the effects of metal dispersion and the origin of the materials used to prepare the catalyst. The extent to which each of these factors plays a role is unknown and must await further investigation. It is significant to note, though, that Maxted and Ali (18) have observed that the activity of Pd for the hydrogenation of cyclohexene depends on the composition of the support, the origin of the support and the loading of $\mathrm{Pd}$.

The present knowledge of the interactions between $\mathrm{Pd}$ and metal oxide supports is inadequate to permit the development of a satisfactory interpretation for the effects of support composition on the activity of Pd for the synthesis of methanol and hydrocarbons. However, since there has been some discussion in the recent literature concerning the influence of metal-support interactions on the chemisorptive and catalytic properties of transition metals, it is instructive to 
review these efforts in order to determine whether the conclusions drawn might help to explain at least a part of the present results.

Strong evidence for the influence of metal-support interactions on the chemisorption of $\mathrm{H}_{2}$ and $\mathrm{CO}$ has been presented recently by Tauster et a1. $(19,20)$. Theix results have shown that the $\mathrm{H}_{2}$ and $\mathrm{CO}$ chemisorption capacities of $\mathrm{Ru}, \mathrm{Rh}_{3} \mathrm{Pd}, \mathrm{Os}$, Ix, and $\mathrm{Pt}$ supported on $\mathrm{TiO}_{2}$ (19) and the $\mathrm{H}_{2}$ chemisorption capacity of Is supported on $\mathrm{TiO}_{2}, \mathrm{~V}_{2} \mathrm{O}_{3}, \mathrm{Nb}_{2} \mathrm{O}_{5}$, and $\mathrm{Ta}_{2} \mathrm{O}_{5}$ decrease with an increase in the temperature at which the supported metal is reduced in hydrogen. Electron microscopy and $x$-ray diffraction showed that these losses in chemisorption capacity were not due to metal agglomeration. It was suggested, therefore, that reduction at high temperatures gives rise to a strong metal support interaction (SMSI) and that the occurrence of SMSI properties depends on the ease with which the metal oxide can be reduced.

Tauster et a1. (19) proposed that the SMSI properties of $\mathrm{TiO}_{2}$ might be explained in texms of metal-metal bonding between the noble metal and titanium cations or, alternatively, the formation of intermetallic compounds. Support for the first of these possibilities has been presented by Horsley (21), based on SCF-Xa molecular orbital calculations for molecular cluster models of $\mathrm{Pt} / \mathrm{TiO} 2^{\circ}$ These calculations favor a structure in which Pt atoms are inserted into surface oxygen vacancies in the support, with bonding between the titanium cations and the Pt atoms. Horsley suggested that if the Pt-Ti bonds were stronger than the Pt-Pt bonds, then Pt atoms would be preferentially attracted to surface anion vacancies formed by reduction of $\mathrm{TiO}_{2}$ rather than to other Pt atoms. Such an occurrence would explain the epitaxial growth of thin rafts of $\mathrm{Pt}$ atoms on $\mathrm{TiO}_{2}$ (22). It was speculated that 
the absence of corner atoms of steps in the rafts of Pt atoms might explain the suppression of $\mathrm{H}_{2}$ chemisorption, since such sites have been claimed to be necessary for the dissociative chemisorption of $\mathrm{H}_{2}$ (23).

The relevance of SMSI effects to the present work is unclear. of the supports used here, only $\mathrm{TiO}_{2}$ has been demonstrated to exhibit SMSI activity, and, based on the work of Tauster and Fung (20) with Ir/TiO, one could anticipate that $\mathrm{Pd} / \mathrm{TiO}_{2}$ reduced at $573 \mathrm{~K}$ should exhibit such activity. However, since the $\mathrm{H}_{2}$ chemisorption capacity of this catalyst was not unusually low, SMSI effects cannot be invoked automatically. This does not rule out the possibility, though, that $\mathrm{Pd}$ on $\mathrm{TiO}_{2}$ and on other supports experiences weaker metal-support interactions which, while not markedly affecting the chemisorption characteristics of the metal, may still influence its catalytic properties.

Based upon results obtained by Figueras et al. (24) and Van Hardeveld and Hartog (25), Vannice (17) has suggested that the higher methanation activities of $\mathrm{Al}_{2} \mathrm{O}_{3}$ and $\mathrm{SiO}_{2}$-supported $\mathrm{Pd}$, compared to $\mathrm{Pd}$ black, might be ascribed to an enhanced formation of weakly bound, linearly adsorbed CO species. It was reasoned that such an enhancement could be due to a decrease in metal crystallite size or to a metalsupport electron transfer which might result in the stabilization of surface structures not normally present on large metal crystallites. While such an explanation might also be invoked to explain the higher hydrocarbon synthesis activities observed using the $\mathrm{La}_{2} \mathrm{O}_{3}, \mathrm{ZrO}_{2}$, and $\mathrm{TiO}_{2}$ supported palladium catalysts described here, the experimental evidence needed to support such an interpretation is not available.

In the studies reported by Ichikawa $(2-5)$ it was suggested that the acidity or basicity of the support has a significant influence on the 
selectivity of the products formed from $\mathrm{CO}$ and $\mathrm{H}_{2} \cdot$ Basic supports were observed to promote the formation of oxygenated products while acidic supports favored the formation of hydrocarbons. Examination of the present results in terms of the acidity or basicity of the support confirms that the highest methanol selectivities are observed on the most basic oxide supports $\left(e . \mathrm{g}_{0}, \mathrm{La}_{2} \mathrm{O}_{3}, \mathrm{MgO}_{2} \mathrm{ZnO}\right)$. The case of $\gamma-\mathrm{Al}_{2} \mathrm{O}_{3}$ is anomalous however, since a high selectivity for oxygenated products is observed over a support which is strongly acidic. Thus, it is not clear to what extent acidity or basicity of the support plays a dominant role in defining the selectivity of supported Pd.

A clearer relationship can be established between support acidity and the formation of dimethyl ether. The results presented in Table 2 and Fig. 3 show that the highest activities for dimethyl ether formation are exhibited by $\mathrm{Pd}$ supported on $\mathrm{\gamma}-\mathrm{Al}_{2} \mathrm{O}_{3}$ and $\mathrm{TiO}_{2} \cdot$ Both supports are acidic (26) and are known to catalyze the formation of dimethyl ether during the decomposition of methanol $(27,28)$. The lower rate of dimethyl ether formation over $\mathrm{TiO}_{2}$ compared to $\mathrm{Al}_{2} \mathrm{O}_{3}$ is most likely attributable to the lower strength and concentration of acid sites on $\mathrm{TiO}_{2}$ (26). Consistent with this trend, it is observed that very little dimethyl ether is formed for $\mathrm{Pd}$ supported on $\mathrm{MgO}$ or $\mathrm{ZrO}_{2}$, materials which exhibit very small concentrations of acid sites, and that the formation of dimethyl ether is totally suppressed when Pd is supported on basic oxides such as $\mathrm{ZnO}$ and $\mathrm{La}_{2} \mathrm{O}_{3}$ or on a neutral oxide such as $\mathrm{SiO}_{2}$. It is noted further that studies of methanol decomposition over MgO (29), Zno (30), and rare earth oxides (31) also show dimethyl ether formation to be insignificant. Based on these observations, it is concluded that the dimethyl ether observed in these studies results from the decomposition of methanol, subsequent to its formation. 
The exceptionally high activities of $\mathrm{Pd} / \mathrm{TiO}_{2}$ and $\mathrm{Pd} / \mathrm{ZrO}_{2}$ for the synthesis of methane, noted in Table 2 and Fig. 5, agree with Ichikawa's (4) observations at $1 \mathrm{~atm}$, but the origin of this specificity cannot readily be explained. One possibility is that a substantial portion of the methane formed over these catalysts arises from a decomposition of methanol. Carrizosa et al. (28) have reported that methanol will decompose over rutile at $523 \mathrm{~K}$, to produce coke and methane but that coke decomposition on anatase occurs only at temperatures in excess of $673 \mathrm{~K}$. Since the $\mathrm{TiO}_{2}$ used in the present studies consists of $87 \%$ anatase and $13 \%$ rutile (32), it is possible that methanol decomposition on the rutile phase might form methane and carbon. Since hydrogen is always present in the gas phase, the carbon might be expected to undergo rapid hydrogenation instead of producing coke. The extent to which such processes might occur on $\mathrm{ZrO}_{2}$ is uncertain; however, it seems reasonable to expect $\mathrm{TiO}_{2}$ and $\mathrm{ZrO}_{2}$ to exhibit similar characteristics, since both $\mathrm{Ti}$ and $\mathrm{Zr}$ axe part of Group IVB.

\section{CONCLUSIONS}

The results presented in this study indicate that the activity and selectivity of supported Pd catalysts for CO hydrogenation are strongly influenced by the composition of the support and differ significantly from those of Pd black. Utilization of basic metal oxide supports such as $\mathrm{MgO}$, $\mathrm{ZnO}$, and $\mathrm{La}_{2} \mathrm{O}_{3}$ favors the formation of methanol, the selectivity to this product exceeding $98 \%$. High methanol selectivity (98\%) is also observed for $\mathrm{Pd}$ supported on $\mathrm{SiO}_{2}$, a neutral oxide. When an acidic metal oxide such as $\mathrm{Al}_{2} \mathrm{O}_{3}, \mathrm{TiO}_{2}$, or $\mathrm{ZrO}_{2}$ is used as the support, the methanol selectivity is suppressed at the expense of forming hydrocarbons. Acidic sites on the support also appear to be responsible for converting a part of the methanol formed 
to dimethyl ether. The manner in which the acid/base properties of the support express their influence on the catalytic properties of Pd is not understood at present. An electronic interaction between the metal and the support is suggested but it appears that this interaction is not of the SMSI-type discussed in the literature $(18,19)$.

other factors besides the support composition may also influence the activity and selectivity of $P d$, among these being the nature of the Pd precursor, the loading and/or dispersion of $P d$, the source of the support and the manner of catalyst pretreatment. Thus, for example, the exceptionally high activity and selectivity of the $\mathrm{Pd} / \mathrm{La}_{2} \mathrm{O}_{3}$ catalyst described in these studies may be due to its preparation by reaction $\mathrm{Pd}\left(\pi-\mathrm{C}_{3} \mathrm{H}_{5}\right)_{2}$ with hydroxyl groups present on the support. The extent to which each of the factors noted exerts an effect on catalyst performance is not yet established and must await further investigation.

\section{ACKNOWLEDGMENT}

The authors wish to thank Dr. Jule A. Rabo of the Unton Carbide Corporation for donation of the catalyst sample designated as $\mathrm{Pd} / \mathrm{SiO}_{2}$ (II). This work was supported by the National Science Foundation under Grant 78-18989-BELL-ZF 04/80 and by the Director, Office of Energy Research, Office of Basic Energy Sciences, Chemical Sciences Division of the U.S. Department of Energy, under Contract 非-7405-ENG-48. 


\section{REFERENCES}

1. Poutsma, M. L., Elek, L. F., Ibarbia, P. A., Risch, A. P., and Rabo, J. A., J. Catal., 52, 157 (1978).

2. Ichikawa, M., J. C. S. Chem. Comm., 566 (1978).

3. Ichikawa, M., Bu11. Chem. Soc. Japan, 51, 2268, 2273 (1978).

4. Ichikawa, M., Shokubai, 21, 253 (1979).

5. Ichikawa, M., and Shikakura, K., Preprints, The Seventh International Congress on Catalysis, Tokyo, July 1-2, 1980.

6. Yermakov, Yu. I., Catal. Rev. Sci. Eng., 13, 77 (1976).

7. Ryndin, Yu. A., Ph.D. thesis, Institute of Catalysis, Novosibirsk, U.S.S.R. 1977.

8. Rosynek, M. P. and Magmeson, D. T., J. Catal., 46, 402 (1977).

9. Anderson, P. J., Trans. Farad, Soc., 61, 2754 (1965).

10. Lewis, K. E., Trans. Farad. Soc., 62, 204 (1966).

11. Tretyakov, N. E. and Pozdnyakov, D. V., Russ. J. Phys. Chem, 44 , 107 (1970).

12. Benson, J. E., Hwang, H. S., and Boudart, M., J. Cata1., 30, 146 (1973).

13. Freel, J., J. Cata1., 25, 139 (1962).

14. Gruber, H. L., Anal. Chem。, 34, 1828 (1962)。

15. Farrauto, R. J., AIChE Symp. Ser. No. 143, 70, 9, 1974.

16. Aben, P.C., J. Catal., 10, 224 (1968).

17. Vannice, M. A., J. Catal., 40, 129 (1975).

18. Maxted, E. B., and Ali, S. I., J. Chem. Soc., 4137 (1961)。

19. Tauster, S. I., Fung, S. C., and Garten, R. L., J. Am. Chem. Soc., $100,170(1978)$.

20. Tauster, S. J., and Fung, S. C., J. Catal., 55, 29 (1978).

21. Horsley, J. A., J. Am. Chem. Soc., 101, 2870 (1979).

22. Baker, R. T. K., Prestridge, E. B., and Garten, R. L., J. Catal., 56, 390 (1979).

23. Christmann, K., and Ertl, G., Surface Sci., 60, 365 (1976). 
24. Figueras, F., Gomez, R., and Primet, M., Adv. Chem. Ser., 121, 480 (1973).

25. Van Hardeve1d, R., and Hartog, F., Adv, Cat., 23, 75 (1972).

26. Tanabe, K., "Solid Acids and Bases", Academic Press, New York, 1970.

27. Matsushima, T., and White, J. M., J. Cata1., 44, 183 (1976).

28. Carrizosa, I., Munvera, G., and Castañar, S., J. Cata1., 49, 265 (1977).

29. Foyt, D. C., and White, J. M., J. Catal., 47, 260 (1977).

30. Ueno, A., Onishi, T., and Tamaxu, K., Trans. Farad. Soc., 67, 2585 (1971)。

31. Rosynek, M. P., Cata1. Rev. Sci. Eng., 16, 111 (1977).

32. Gravelle, P. C., Juillet, F., Meriaudeau, P., and Teichner, S. J., Disc. Farad. Soc. 52, 140 (1971). 
Table 1 Support and Catalyst Characteristics

\begin{tabular}{|c|c|c|c|c|c|c|}
\hline Catalyst & $\begin{array}{l}\text { Source of } \\
\text { Support }\end{array}$ & $\begin{array}{l}\text { Support Surface } \\
\text { Area }\left(\mathrm{m}^{2} / \mathrm{gm}\right)^{c}\end{array}$ & $\begin{array}{l}\text { Dehydration } \\
\text { Temp. (K) }\end{array}$ & $\begin{array}{l}\text { Pd Loading } \\
\text { (wt. \%) }\end{array}$ & $\mathrm{D}_{\mathrm{Pd}}$ & $\begin{array}{l}\text { Catalyst } \\
\text { Charge (gm) }\end{array}$ \\
\hline $\mathrm{Pd} / \mathrm{MgO}$ & Mallinckrodt & 100 & 873 & 0.3 & 0.20 & 0.57 \\
\hline $\mathrm{Pd} / \gamma-\mathrm{Al}_{2} \mathrm{O}_{3}$ & Kaiser S-201 & 250 & 873 & 2.1 & 0.40 & 0.55 \\
\hline $\mathrm{Pd} / \mathrm{La}_{2} \mathrm{O}_{3}$ & Ventron & $14^{\mathrm{d}}$ & 493 & 0.2 & 0.23 & 1.04 \\
\hline $\mathrm{Pd} / \mathrm{SiO}_{2}(\mathrm{II})^{\mathrm{a}}$ & Davison 57 & - & - & $7.9(4.6)^{2}$ & $0.17(0.26)^{b}$ & 0.05 \\
\hline $\mathrm{Pd} / \mathrm{TiO}_{2}$ & Degussa P-25 & 50 & 673 & 0.5 & 0.35 & 0.56 \\
\hline $\mathrm{Pd} / \mathrm{ZrO}_{2}$ & Nyacol & 20 & 773 & 0.3 & 0.48 & 1.88 \\
\hline Pd B1ack & - & - & - & - & 0.003 & 0.10 \\
\hline
\end{tabular}

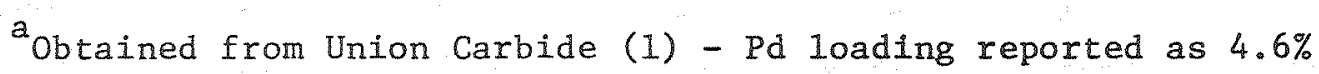

$b_{D_{P d}}$ based on a Pd loading of $4.6 \%$

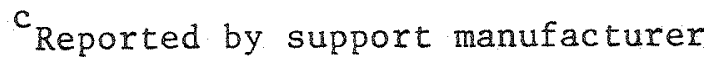

${ }^{d}$ Reported by Rosynek et a1. (8) 
Table 2 Catalytic Properties of Supported and Unsupported Pd

\begin{tabular}{|c|c|c|c|c|c|c|c|c|c|c|c|c|}
\hline \multirow[b]{2}{*}{ Catalyst } & \multirow{2}{*}{$\begin{array}{l}\text { Co } \\
\text { Conv. }(\%)\end{array}$} & \multicolumn{3}{|c|}{$\mathrm{E}_{\mathrm{a}}(\mathrm{kcal} / \mathrm{mole})$} & \multicolumn{4}{|c|}{ Turnover Freq. $\left(\times 10^{3} \mathrm{~s}^{-1}\right)$} & \multicolumn{4}{|c|}{$\mathrm{S}(\%)$} \\
\hline & & $\mathrm{CH}_{3} \mathrm{OH}$ & $\mathrm{CH}_{3} \mathrm{OCH}_{3}$ & $\mathrm{CH}_{4}+\mathrm{C}_{2+}$ & $\mathrm{CH}_{3} \mathrm{OH}$ & $\mathrm{CH}_{3} \mathrm{OCH}_{3}$ & $\mathrm{CH}_{4}$ & $\mathrm{c}_{2+}$ & $\mathrm{CH}_{3} \mathrm{OH}$ & $\mathrm{CH}_{3} \mathrm{OCH}_{3}$ & $\mathrm{CH}_{4}$ & $\mathrm{C}_{2+}$ \\
\hline Pd-Black & 0.01 & 10.2 & - & 23.3 & 0.60 & 0 & 0.07 & 0.13 & 75.0 & 0 & 8.8 & 16.2 \\
\hline $0.3 \% \mathrm{Pd} / \mathrm{MgO}$ & 0.1 & 16.6 & 23.4 & 26.9 & 7.70 & 0.097 & 0.02 & 0.01 & 98.4 & 1.2 & 0.3 & 0.2 \\
\hline $0.2 \% \mathrm{Pd} / \mathrm{ZnO}$ & 0.4 & 17.6 & - & 24.5 & 8.40 & 0 & 0.01 & 0.01 & 99.8 & 0 & 0.1 & 0.1 \\
\hline $1.5 \% \mathrm{Pd} / \mathrm{Al}_{2} \mathrm{O}_{3}$ & 0.1 & 14.2 & 24.6 & 25.9 & 2.61 & 4.920 & 0.26 & 0.07 & 33.2 & 62.7 & 3.3 & 0.8 \\
\hline $0.2 \% \mathrm{Pd} / \mathrm{La}_{2} \mathrm{O}_{3}$ & 0.5 & 14.0 & - & 24.9 & 99.10 & 0 & 0.50 & 0.53 & 99.0 & 0 & 0.5 & 0.5 \\
\hline $1.5 \% \mathrm{Pd} / \mathrm{SiO}_{2}(\mathrm{I})$ & 0.1 & 17.2 & - & 24.1 & 2.33 & 0 & 0.08 & 0.13 & 91.6 & 0 & 3.4 & 5.0 \\
\hline $7.9 \% \mathrm{Pd} / \mathrm{SiO}_{2}(\mathrm{II})$ & 1.5 & 14.1 & - & 25.7 & 18.51 & 0 & 0.28 & 0.03 & 98.3 & 0 & 1.5 & 0.2 \\
\hline $0.5 \% \mathrm{Pd} / \mathrm{TiO}_{2}$ & 0.3 & 16.0 & 23.5 & 23.2 & 4.20 & 0.819 & 4.00 & 0.50 & 44.1 & 8.6 & 42.1 & 5.2 \\
\hline $0.3 \% \mathrm{Pd} / \mathrm{ZrO}_{2}$ & 0.7 & 15.2 & 22.9 & 24.0 & 11.40 & 0.070 & 3.40 & 0.37 & 74.7 & 0.5 & 22.3 & 2.5 \\
\hline
\end{tabular}

Reaction Conditions: $\mathrm{T}=250^{\circ} \mathrm{C} ; \mathrm{P}=10 \mathrm{~atm} ; \mathrm{H}_{2} / \mathrm{CO}=3$ 
Table 3 Stability of Supported and Unsupported $\mathrm{Pd}$

\begin{tabular}{|c|c|c|c|}
\hline Catalyst & $\mathrm{CH}_{3} \mathrm{OH}$ & $\begin{array}{l}\text { E. Stabi. } \\
\mathrm{CH}_{3} \mathrm{OCH}_{3}\end{array}$ & $\mathrm{CH}_{4}+\mathrm{C}_{2+}$ \\
\hline Pd-Black & stable & - & Stable \\
\hline $0.3 \% \mathrm{Pd} / \mathrm{Mgo}$ & Inc. & Stable & Stable \\
\hline $0.3 \% \mathrm{Pd} / \mathrm{ZnO}$ & Inc. & - & Stable \\
\hline $1.5 \% \mathrm{Pd} / \mathrm{Al}_{2} \mathrm{O}_{3}$ & Inc. & Stable & Stable \\
\hline $0.2 \% \mathrm{Pd} / \mathrm{La}_{2} \mathrm{O}_{3}$ & Stable & - & Stable \\
\hline $1.5 \% \mathrm{Pd} / \mathrm{SiO}_{2}$ (I) & Stable & - & Dec. \\
\hline $7.9 \% \mathrm{Pd} / \mathrm{SIO}_{2}$ (II) & Stable & - & stable \\
\hline $0.5 \% \mathrm{Pd} / \mathrm{TiO}_{2}$ & Inc. & Stable & Stable \\
\hline $0.3 \% \mathrm{Pd} / \mathrm{ZrO}_{2}$ & Inc. & Stable & Stable \\
\hline
\end{tabular}


Table 4. Comparison of $\mathrm{Pd} / \mathrm{La}_{2} \mathrm{O}_{3}$ Catalysts

\begin{tabular}{lccccc}
\hline Ref. & Catalyst & \multicolumn{2}{c}{$\mathrm{E}_{\mathrm{a}}$ (kcal/mole) } & \multicolumn{2}{c}{ Reaction Rate (mmole/hr.gm Pd) } \\
& & $\mathrm{CH}_{3} \mathrm{OH}$ & $\mathrm{CH}_{4}$ & $\mathrm{CH}_{3} \mathrm{OH}$ & $\mathrm{CH}_{4}$ \\
\hline Ichikawa (4) & $2.9 \% \mathrm{Pd} / \mathrm{La}_{2} \mathrm{O}_{3}$ & 13.0 & 29.0 & $40.3^{\mathrm{a}}$ & $1.96^{\mathrm{b}}$ \\
This work & $0.2 \% \mathrm{Pd} / \mathrm{La}_{2} \mathrm{O}_{3}$ & 14.0 & 24.9 & 871.0 & 4.70 \\
\hline
\end{tabular}

Reaction Conditions: $\mathrm{T}=250^{\circ} \mathrm{C} ; \mathrm{P}=10 \mathrm{~atm} ; \mathrm{H}_{2} / \mathrm{CO}=3$

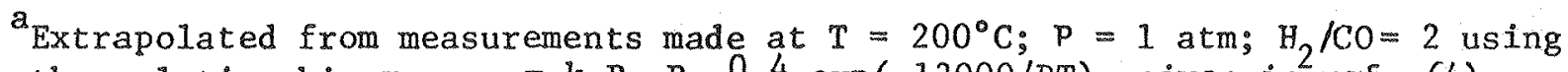
the relationship ${ }^{\mathrm{T}} \mathrm{CH}_{3} \mathrm{OH}=\mathrm{k}_{1} \mathrm{P}_{\mathrm{H}_{2}}{ }^{\mathrm{P}} \mathrm{CO}{ }^{0.4} \exp (-13000 / \mathrm{RT})$, given in ref. (4).

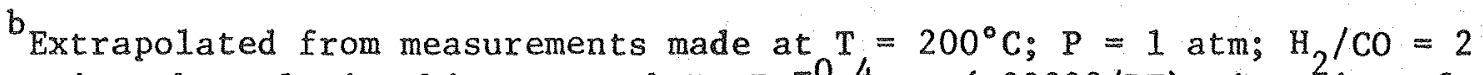
using the relationship ${ }^{{ }_{C H}}={ }_{2}{ }_{2}{ }{ }_{H_{2}}{ }{ }_{C O}-0.4 \exp (-29000 / R T)$ given in ref. (4). 


\section{FIGURE CAPTIONS}

Fig. 1 Dependences of the methanol and hydrocarbon formation rates over $\mathrm{Pd} / \mathrm{SiO}_{2}$ (I) and $\mathrm{Pd} / \mathrm{ZnO}$ as functions of the number of consecutive runs performed

Fig. 2 Arrhenius plots for the formation of methanol: $P=10$ atm; $\mathrm{H}_{2} / \mathrm{CO}=3$.

Fig. 3 Arrhenius plots for the formation of dimethyl ether: $P=10$ atm; $\mathrm{H}_{2} / \mathrm{CO}=3$.

Fig. 4 Arrhenius plots for the formation of hydrocarbons: $P=$ $10 \mathrm{~atm} ; \mathrm{H}_{2} / \mathrm{CO}=3$.

Fig. 5 Percentage of the $\mathrm{CO}$ converted to hydrocarbons containing 1 to 6 carbon atoms: $\mathrm{T}=250^{\circ} \mathrm{C} ; \mathrm{P}=10 \mathrm{~atm} ; \mathrm{H}_{2} / \mathrm{CO}=3$. 


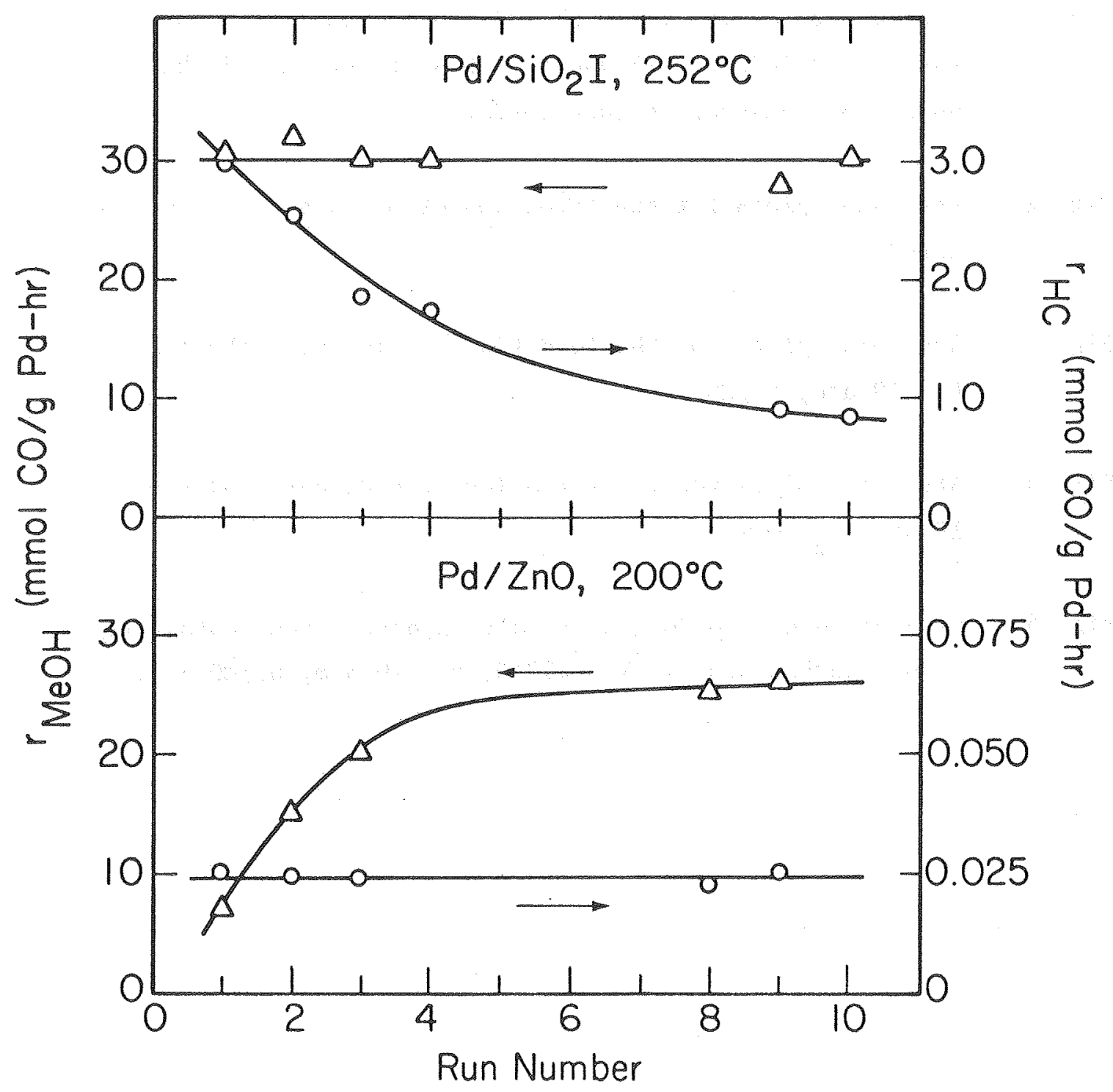

XBL $813-8597$ 


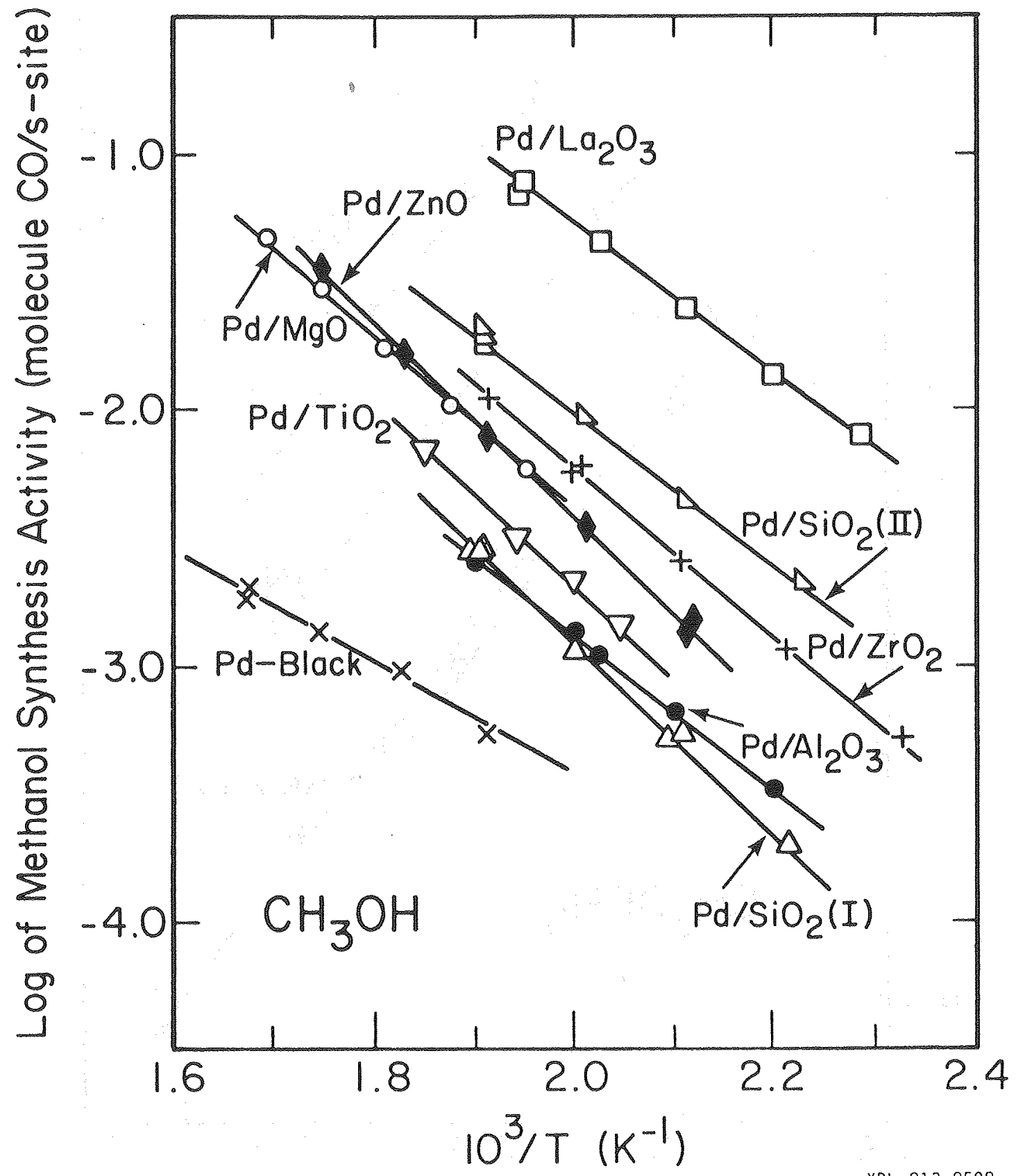

XBL $\quad 813-8598$ 


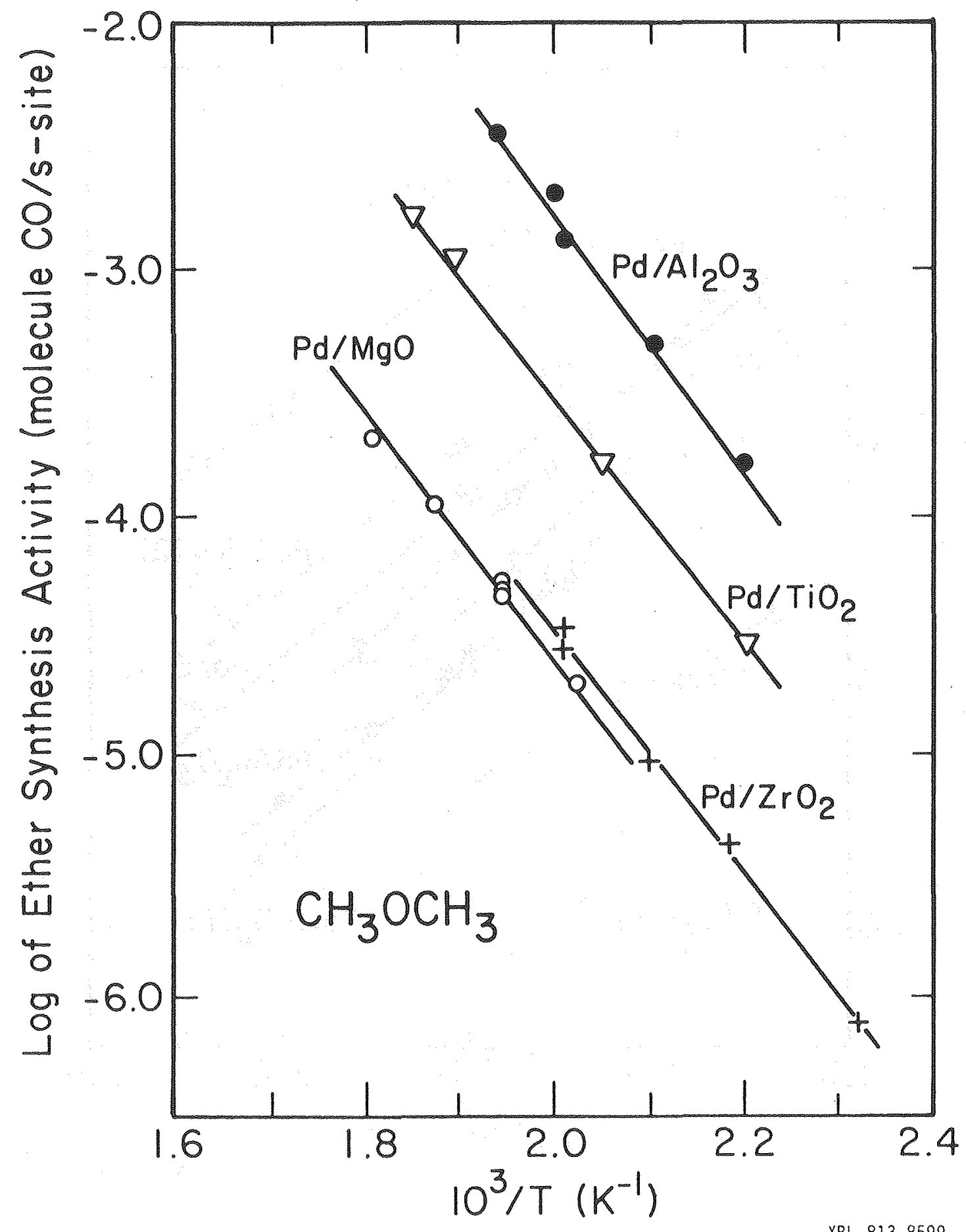




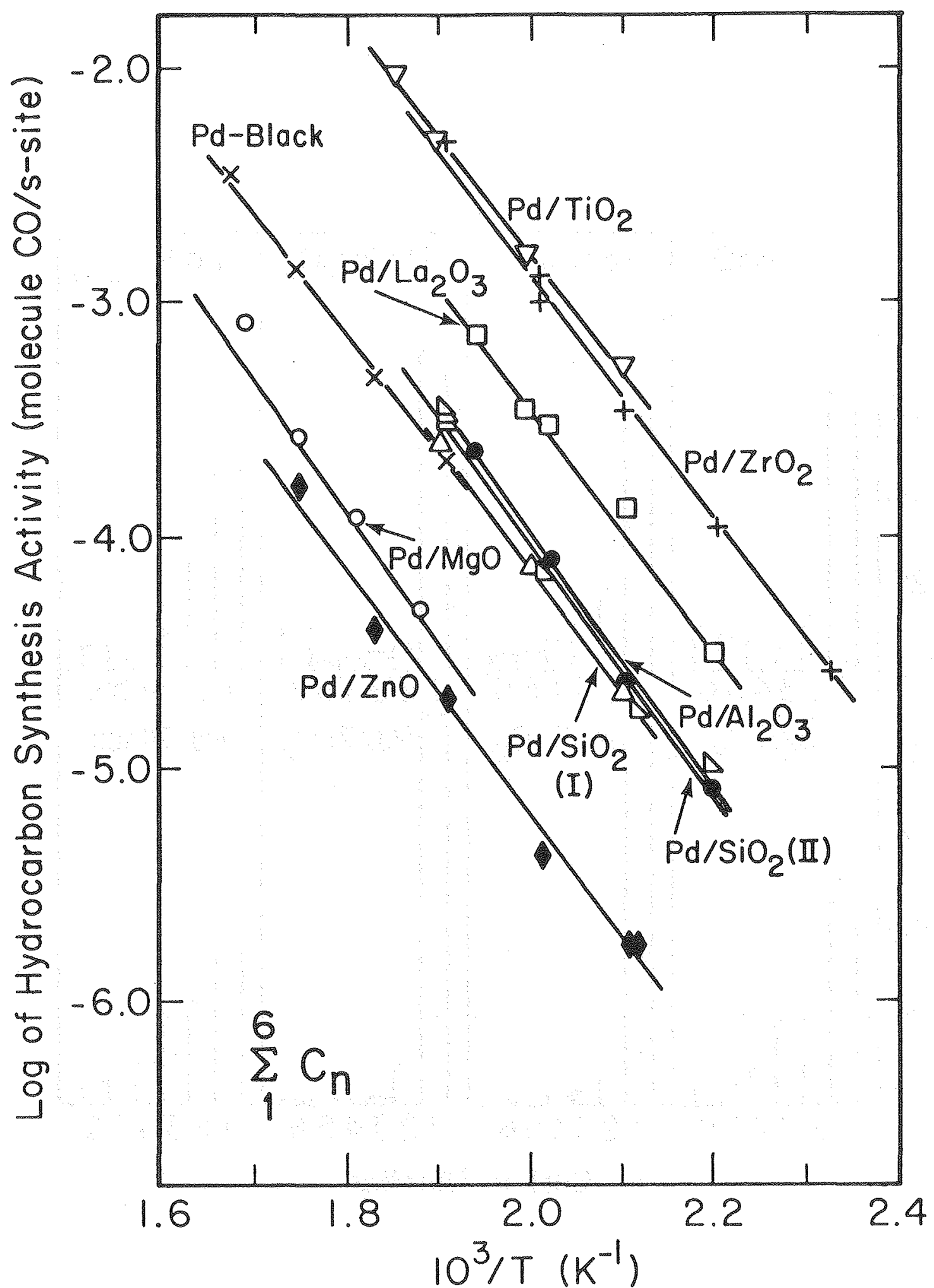

XBL $813-8600$ 


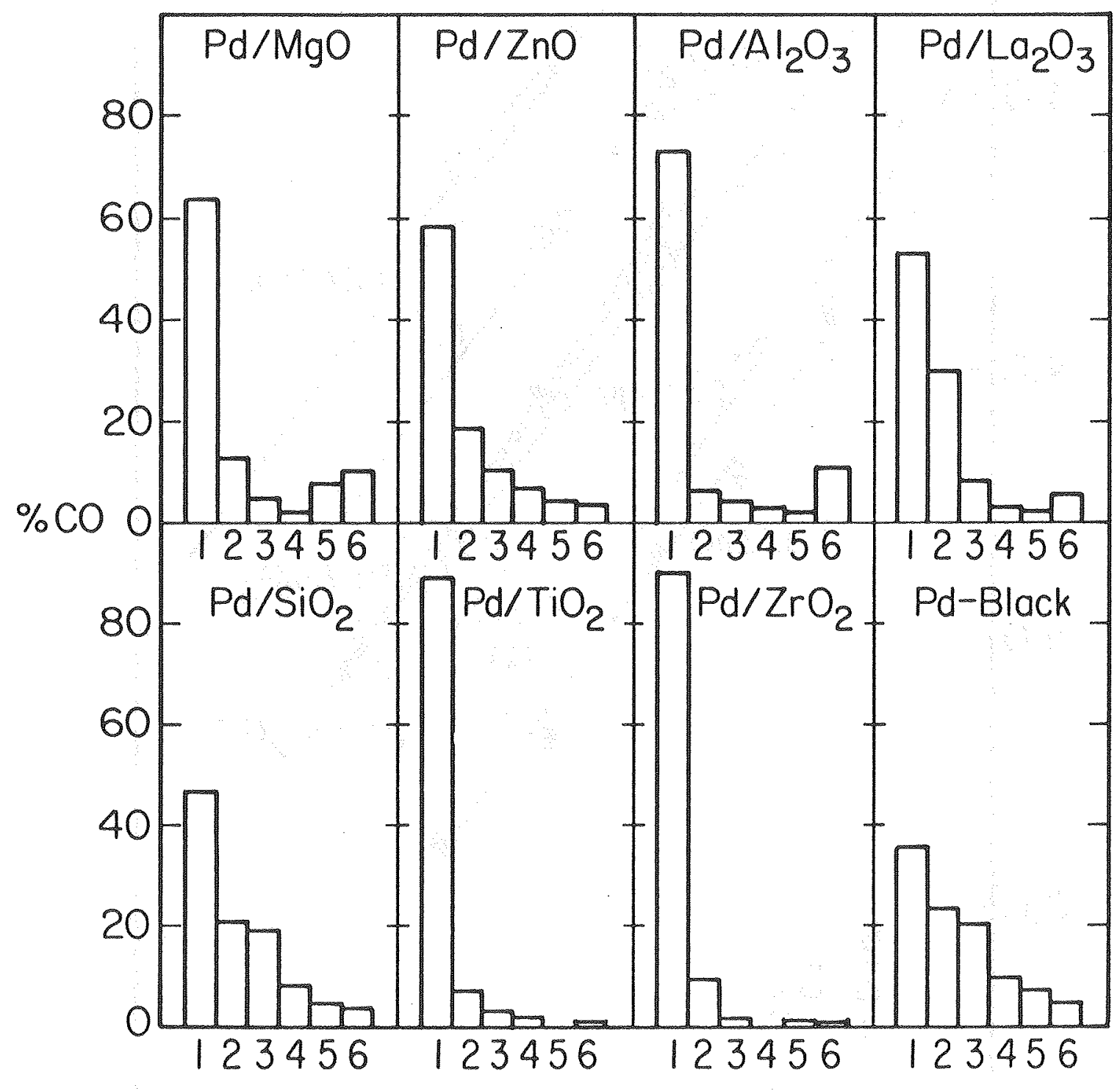

Carbon Number 